\title{
A STRATEGIC VISION OF PAKISTAN'S INTERNAL SECURITY DYNAMICS
}

\author{
Ayaz Ahmed Khan*
}

\begin{abstract}
Present era can be categorized due to its speed of changes. Pakistani society got affected by worst kind of terrorism and extremism in last fifteen years. The root causes of prevailing security environment in Pakistan are multifaceted, complex and are derived from structural, as well as micro-level conditions. Objective of this research is to highlight the gaps in security doctrine of Pakistan. Both qualitative and quantitative methodology in the format of Knowledge Attitude and Practice (KAP study) is selected. Primary question of this research was to find the gaps in national internal security policy of Pakistan. This primary question is further sub divided into ten sub questions. Implementation modalities and the impediments of National Internal Security Policy (NISP) 2014 are also discussed. This research finds out that national internal security policy 2014 was a vibrant document and right step in the domain of policy formulation but demanded non-pragmatic results from security operators. Majority of its drawbacks are removed in in its later version of 2018-23. Survey and questionnaire based analysis is also made part of this article along with recommendations as submitted by respondents.
\end{abstract}

Keywords: Internal security, security policy, National Action Plan, NISP 2018, extremism, ideological security

\section{Introduction}

The long awaited global peace expectations hoped by the end of the cold war have not turned into sheer reality. National interests are of prime concern in bi-lateral or multilateral relations between the states and the concept of regional security is gaining attention. ${ }^{2}$ This likely overtakes and counter narrative by USA has brought the focus of attention towards Asia pacific issues. ${ }^{3}$ In south Asia, Americans are focusing to attain their policy objectives though India and Afghanistan to contain China and Russia. Pakistan is facing grave and diverse security challenges and a complex threat, an extremely cunning hostile enemy on east who always stages all kind of clandestine operations against Pakistan. ${ }^{4}$ On the western border, Afghanistan has always remained a

\footnotetext{
* Ayaz Ahmed Khan, Ph.D. Scholar, Department of International Relations, University of Karachi

2 Alan K. Henrikson "The United States in a Global Triangle? Re-configuring US-EU and US-China Foreign Policy and Security Relations.” The Evolving Relationship between China, the EU and the USA: A New Global Order? (2019).

${ }^{3}$ John Hurley, Scott Morris, and Gailyn Portelance. "Examining the Debt Implications of the Belt and Road Initiative from a Policy Perspective." Journal of Infrastructure, Policy and Development 3, no. 1 (2019): 139175.

${ }^{4}$ Muhammad Saleem Mazhar, and Naheed S. Goraya. "External Challenges to Pakistan's National Security." Journal of the Research Society of Pakistan 56, no. 1 (2019): 117.
} 
source of instability for Pakistan. ${ }^{5}$ US policy botches in Afghanistan, Iran and Middle East along with wishful demands of Trump administration from Pakistan without acknowledging its sacrifices are a matter of concern. ${ }^{6}$ To retain their national interests transition-co forces are using fifth generation asymmetric warfare in this region. ${ }^{7}$ This is fueling the terrorism and proxy wars in the region. Newly adopted hybrid warfare ${ }^{8}$ mainly focuses on economic objectives of targeted country where states become irrelevant without firing a single bullet. ${ }^{9}$ In South Asia, unfortunately, peace and stability index has never shown good indicators. Concrete efforts for peace and stability may it be intra-state or inter-state were very less because this region needs extra-ordinary steps for better security conditions. On the other side challenges of overpopulation, ${ }^{10}$ poverty,${ }^{11}$ weak health, education and terrorism are more pulsating and predominant in this region. ${ }^{12}$

Pakistan also faces regional security challenges and is susceptible to any eastern or western security dilemma due kinetic and non-kinetic operations by hostile elements. Moreover, Pakistanis are highly charged society domestically which if not channelized in right direction can be exploited by its enemy and lead towards internal implosion. Any future battle in this region would be in physical as well as in cognitive domain which can be won by altering/ invading leadership, economy or regime. Enemies of Pakistan would try their level best to denude by declaring Pakistan a plaint state. Abovementioned regional/global security situation and active involvement of Pakistani forces in Global war on terror have manifested/confronted Pakistan with multiple asymmetrical security threats which are challenging the sovereignty of Pakistan. This strategic security calculus of Pakistan demands a prudent and vibrant internal security doctrine and its explicit manifestation in national internal security policies.

This article is an analysis of Pakistan's national internal security policies from 2014 onwards and its voids. The research work is carried out to analyze the security directions set by national internal security policy of 2014 and its improved version in 2018 . The practical implementation and impediments of this policy along with functioning of NACTA and progress made to accomplish national action plan are briefly discussed. Few recommendations are also proffered at the end to improve the overall security environment in Pakistan.

\footnotetext{
${ }^{5}$ Maryam Azam, "Genesis and Dimensions of Religious Militancy: Implications on the Internal Security of Pakistan (2001-2015)." PhD diss., (Lahore: University of the Punjab, 2019).

${ }^{6}$ Baqir Sajjad Syed, "Pak-US Ties Dip to New Low after Trump's Rant" Daily Dawn, (Karachi: November 20, 2018).

${ }^{7}$ Baqir Sajjad Syed, "Hybrid War Imposed on Country to Internally Weaken it", says Bajwa" Daily Dawn, (Karachi: April 15,2018).

${ }^{8}$ Robert Johnson, "Hybrid War and Its Countermeasures: A Critique of the Literature." Small Wars \& Insurgencies 29, no. 1 (2018): 141-163.

9 James K Wither, "Making Sense of Hybrid Warfare," Connections: The Quarterly Journal 15, no. 2 Harvard (2016): 5-7.

${ }^{10}$ Rana Nabeel Ahmed and Kahlil Ahmad. "Impact of Population on Economic Growth: A Case Study of Pakistan." Bulletin of Business and Economics (BBE) 5, no. 3 (2016): 162-176.

${ }_{11}$ Hummera Saleem, and Muhammad Bilal Khan, "Multidimensional Poverty in Pakistan: A Policy Perspective." In Proceedings of the 4th International Conference on Poverty and Sustainable Development, vol. 4, pp. 35-51. 2017.

${ }^{12}$ Masood Ur Rehman Khattak, and Mansoor Akbar Kundi. "Conventional Asymmetries between India and Pakistan: A threat to the Deterrence Stability of South Asia." Journal of Political Studies 26, no. 1 (2019).
} 


\section{Literature Review}

According to Sigmund Freud human behaviour, including violent behaviour, is the product of "unconscious" forces operating within a person's mind. To understand the phenomenon of extremism and insecurity in Pakistan, psychological and behavioral theories are also consulted. Theory of ego identity formulation by Erik Erikson's 1959, Novelty-Seeking Theory of Victoroff, $2005^{13}$, Social Learning Theory of Bandura, 1973$1998^{14}$, Frustration-Aggression Theory by Davies, 1973 Merton, 1938 ${ }^{15}$; Cantor Land, 1985 and Aseltine 2000, Relative Deprivation Theory by Ted Robert Gurr 1936-2017 ${ }^{16}$ from his famous book 'Why Men Rebel' 1970, Rational Choice Theory proposed by Sandler, Tschirhart and Cauley 1983, Lapan 1988 ${ }^{17}$; Crenshaw 1992; Wilson 2000, and Routine activities theory by Cohen and Felson $1979^{18}$ are referred to view the root causes of extremism however to remain relevant and focused with main study only the generalized causes of insecurity in Pakistan are discussed.

The root causes of prevailing security environment in Pakistan are multidimensional. ${ }^{19}$ Some drivers of prevailing security environment in Pakistan are proximate in time and space, and operate at the individual level to spread radicalization. Others still are intermediate and long-term and can create macro-level conditions and forces required for generating and sustaining violent extremism. The first of these root categories can be termed structural push factors. These are state repression, endemic conflict, entrenched corruption, elite impunity, social fragmentation, cultural threat narratives, low literacy levels, poverty, unemployment, identity crisis, personal glory/fame and social networks.

Extremism is a mindset where only a single truth is considered to be valid. ${ }^{20}$ It is the antithesis of liberalism. ${ }^{21}$ Education is the carrier of liberal values. It is the natural enemy of extremism because it enriches and broadens the mind, enables one to entertain a thought without necessarily accepting it and creates willingness to live in a society that is democratic, pluralistic and diverse. According to the recent National Human Development Report published in May 2018, Pakistan has the largest percentage of youth

${ }^{13}$ Birga M. Schumpe, Jocelyn J. Bélanger, Manuel Moyano, and Claudia F. Nisa. "The Role of Sensation Seeking in Political Violence: An Extension of the Significance Quest Theory." Journal of Personality and Social Psychology (2018).

${ }^{14}$ Albert Bandura, and Richard H. Walters. Social Learning Theory. Vol. 1. Englewood Cliffs, NJ: PrenticeHall, 1977.

${ }^{15}$ Ross, Jeffrey Ian. "A Model of the Psychological Causes of Oppositional Political Terrorism." Peace and Conflict 2, no. 2 (1996): 129-141.

${ }^{16}$ Ted Robert Gurr, Why men rebel. Routledge, 2015.

${ }^{17}$ Todd Sandler, John T. Tschirhart, and Jon Cauley. "A Theoretical Analysis of Transnational Terrorism." American Political Science Review 77, no. 1 (1983): 36-54.

${ }^{18}$ Felson, Marcus. "Linking Criminal Choices, Routine Activities, Informal Control, and Criminal Outcomes." in The Reasoning Criminal, (Routledge, 2017): 119-128.

${ }^{19}$ Abdul Hameed, and Shahid Karim. "Multidimensional Poverty Mapping for Rural Pakistan." This paper has been presented at $1^{\text {st }}$ International Conference on Business, Economics, \& Education Management-ICBEM

(Sukkur: Institute of Business Administration, 2016).

${ }^{20}$ Abdul Muhaimin, "Encountering Extremism Through a Counter Narrative a Study of the Pakistani Society." (2016).

${ }^{21}$ Lazar Stankov, Goran Knežević, Gerard Saucier, Borislav Radović, and Biljana Milovanović. "Militant Extremist Mindset and the Assessment of Radicalization in the General Population." Journal of Individual Differences (2018) 
ever recorded in its history. ${ }^{22}$ Sixty four percent of the total population is below the age of 30 while 29 percent is between the ages of 15 and 29 years. This youth bulge has critical implications for Pakistan because if not groomed and directed in right direction, may create internal implosion. Enemies of Pakistan precisely identified its youth and educational institutes as the centers of gravity and attacking it with numerous means. Pakistan's most exquisite asset is her youth and it must be protected from extremism.

\section{Genesis of Pakistan's Internal Security Turbulence}

Amplification of terrorism in Pakistan can relate to the US led jihad against Soviet forces in Afghanistan. At that time, United States presented Islamic concept of jihad as a legitimate way to fight the oppressors. Religious sentiments and cultural similarities of the masses, between tribal areas of Pakistan and Afghanistan were exploited for vested interest of US. However, after the withdrawal of the Soviet Union from Afghanistan, the US made an impulsive exit from the region. Mujahedeen groups that had been trained and supported by CIA under American patronage, became highly charged morphed entities and ultimately got control of the whole Afghanistan. ${ }^{23}$ These groups later on formed Taliban government but 9/11 was the event which overnight triggered a new wave of militancy in both Afghanistan and Pakistan. Yesterdays' western poppets overnight declared terrorists and a full scale war has been crafted against Afghan Talibans by NATO. Pakistan although joined this US-led international coalition against terrorism but the relationship between US and Pakistan as well as Pakistan and Afghanistan in this time frame witnessed a major transformation and within two years of joining the coalition (formed in 2001), Pakistan realized that, it had opened a pandora box for itself and instability in Afghanistan has evocatively started creeping into Pakistan.

\section{National Internal Security Policies of Pakistan}

Actually there are host of security challenges and dilemmas and each dilemma justifies a reason, but perhaps no problem is as grave as the disconsolate professional eminence of the government policies in this regard. National internal security policy of any country is the most important document to organize its security structure and devise a strategy to fight against terrorism. Since the inception of Pakistan, number of laws were formulated to handle various security situations, however a focused policy which counters the blow of contemporary, vivacious and evolving threats was a missing area. Government of Pakistan launched its National Internal Security Policy (NISP-2014) on February 25, 2014. This is graded as first comprehensive policy on the subject, however this is another discussion that this policy was made under compulsion and not as a routine mater of legislation. $^{24}$

\footnotetext{
${ }^{22}$ Ayaz Khan, "Education Sector of Pakistan Next Victim of Terrorism." Pakistan Journal of International Affairs 2, no. 1 (2019)

${ }^{23}$ Bawa Singh, "Peace-making in Afghanistan: Heart of Asia is in Question?" FOCUS 1, no. 28 (2017): 16

${ }^{24}$ Zahid Yaseen, and Muhammad Muzaffar. "Extremism in Pakistan: Issues and Challenges." Journal of Politics and International Studies 4, no. 1 (2018): 31-42
} 

to protect the core values of a nation. ${ }^{25}$

Earlier there were counter terrorism laws but it was in bits and pieces and evolved as per necessity over the years to counter the menace of terrorism. NISP-2014 defined the role of National Anti-Terrorism Authority (NACTA) and also defines the policy framework of National Action Plan (NAP). This policy was implemented by Ministry of Interior in order to improve the security situation of Pakistan and it achieved the desired results. However, some areas still require improvement and these are focused in the new edition of internal security policy of 2018-23.

\section{National Action Plan}

Brutal terrorist attacks of Army Public School (APS) Peshawar on 16 December 2014, causing great shock, pain and anger gave birth to a comprehensive and holistic plan in shape of "National Action Plan". ${ }^{26}$ It evolved with input from all segments of the government and non-governmental avenues with unanimous consensus to root out terrorism, militancy and extremism from Pakistan. National Action Plan (NAP) comprising twenty points, was spearheaded by military to dismantle the terrorist networks within the country. Elementary idea of twenty-points National Action Plan is to flush out terrorism from Pakistan. Because it was required that a remedial and castigatory action might be originated against terrorists. Operation Zarb-e-Azab ${ }^{27}$ achieved good results but its onslaught led to extreme security threats in settled parts also, so its perimeters are enhanced for country level with the name of operation Radd-ul-Fasad. The forced implementation on NAP by other state institutions faced a lot of political, diplomatic, administrative and legal hindrances, thus making slow progress in achieving the desired results.

\section{Methodology}

Primary data required is acquired by means of questionnaire surveys/interviews and field notes, subsequently, this data is analyzed using computer software (Microsoft Excel 2016 and Outside Software e-Surveys Pro) while Google play android application Quick Tap Survey is also used for field surveys. Pakistan Institute for Peace Studies (PIPS) digital data base has also been consulted to validate the trends of terrorist attacks and other killings under the shade of sectarian, attack on security forces, cross border/insurgent attacks, drone attacks retaliation and ethno-political violence. The diverse dimensions of Pakistan security threats are interrogated keeping in view its application in futuristic scenario. It is anticipated that based on recommendations of this research, planning process in civilian and military hierarchy may adopt a better course of action. A mix of qualitative and quantitative method under the umbrella of KAP study is applied to

\footnotetext{
${ }^{25}$ National Internal Security Policy 2018-2023, Ministry of Interior, Government of Pakistan, p.27

${ }^{26}$ Khalid A Mufti, Ali Ahsan Mufti, and Michaeline Bresnahan. "The Army Public School Massacre in Peshawar, Pakistan." International Perspective on Disasters and Children's Mental Health, (Springer, Cham, 2019): 63-71

${ }^{27}$ Urwa Elahi, and Umbreen Javaid, “Operation Zarb e Azb: A Decisive Strike.” Pakistan Vision 20, no. 2 (2019)
} 
acquire the most accurate findings about the subject. In this article, I also outlined few recommendations for security sector of Pakistan.

A total of 16 surveys were carried out at Qila Abdulla, Chamman and Quetta districts of Baluchistan while Tank, Hangu and Peshawar districts of KPK. Tribal leaders of Wazir, Burki and Maseed tribes are also interviewed at South Waziristan. Dawar tribe people and Darwesh khel Waziri tribesmen are also contacted for their views at North Waziristan. A simple random sample (i.e., subset of individuals chosen from a larger set throughout the country having some relationship/insight with security management) for interviews were selected. Final composition of the survey is 83 respondents. Endeavor was also made to take the answers directly from the officials actively involved with the current security domain of Counter Terrorism Department (CTD). Religious scholars and off-course academicians related to security and strategic studies departments are also consulted. A valuable input is also appropriated during various international security seminars conducted during 2017-2019.

Discussion (Survey Results/Findings) ${ }^{28}$ Survey results/findings are depicted in following chart:

\section{Description of survey results are discussed in subsequent paragraphs}

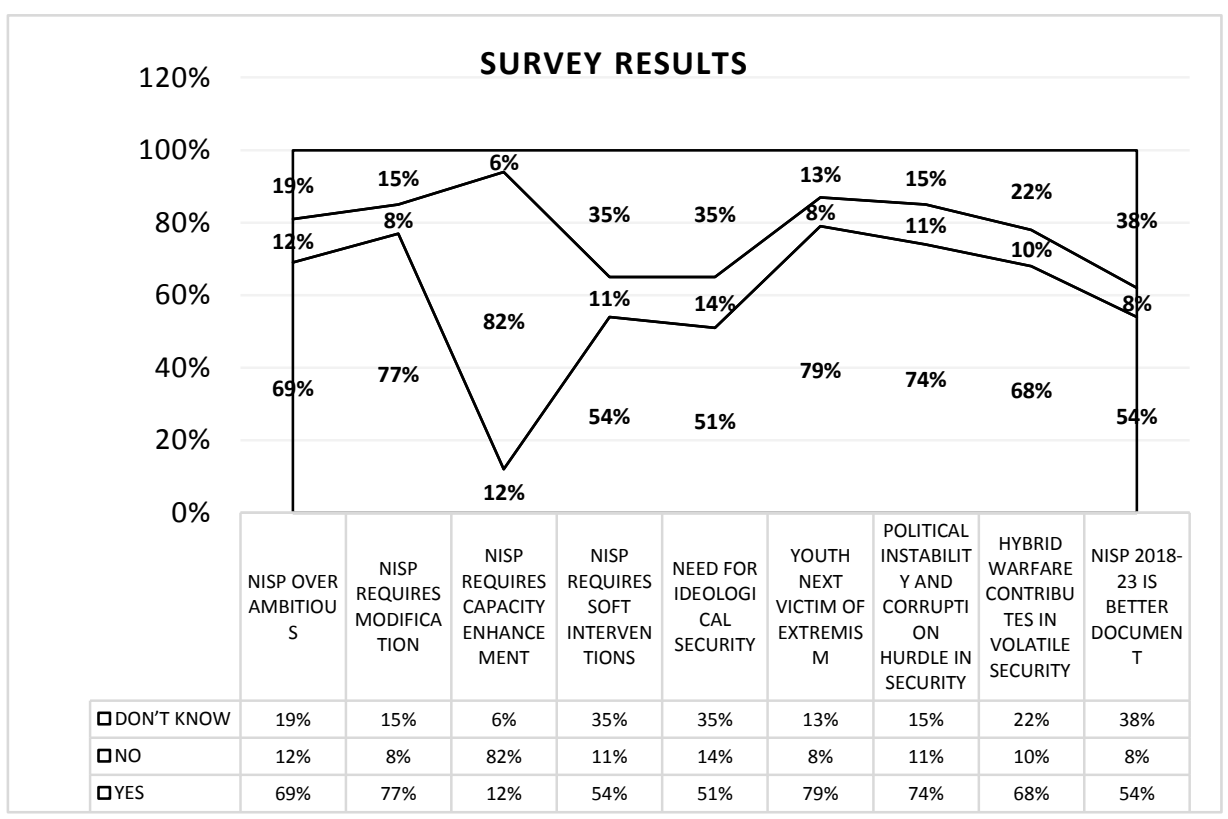

Majority of the respondents believed NISP-2014 was an over-ambitious document because it was not prepared according to the ground realities of Pakistan. Foreign

${ }^{28}$ Questionnaire based survey results of research questions carried out for this article between 2016-2018 
doctrines could not give pragmatic results in Pakistan. National Action Plan (NAP) also required modifications according to the peculiar problems of Pakistan like poor economy, corruption, political instability (different provinces have different political government and again their leaders are involved in corruption cases) and lack of resources. Security agencies of Pakistan require capacity building in terms of equipment, training, morale, professionalism, strength, weapons and techniques to implement NAP of Pakistan in true letter and spirit. Pakistan has to pay special attention to increase its soft power potentials. Application of hard power cannot achieve desired long lasting effects for sustainable peace and growth. Military operations can achieve temporarily results but lasting peace can only be created with human development projects by a democratic government.

Extremism is polluting Pakistani society and its major target is our youth ${ }^{29}$, Pakistan has to invest in the domain of ideological security. However, majority of the respondents were of the view that steps taken by the government in this domain of security were very less and magnitude of the threat may it be extremism or sectarianism is quite large. A massive majority i.e., 79 percent of the respondents think that social media now-a-days is big source of promoting extremism in our society and our youth are highly inclined towards it. During the conduct of these survey new elected government of Pakistan Tahreek-e-Insaaf (PTI) was elected whose basic slogan was change and abolishment of corruption and nepotism from power corridors of Pakistan but still majority of the respondents believe that political instability, culture of nepotism and corruption are the biggest hurdles in improving the security situation of Pakistan.

Pakistan's culture of corruption can be traced back to the early 1970 s...... Pakistan's moment of truth has now arrived. The mandate the people have given to the PTI clearly means they want something to be done about this cancer, eating away at our country..... We cannot afford any "sacred cow. ${ }^{30}$

Majority of the respondents agreed that hybrid warfare techniques used by anti- Pakistan elements and hostile countries in Pakistani neighborhood are a serious reason of poor security conditions in Pakistan. Number of people talked about Indian spy Kulbhushan Yadav and criticized India for sponsoring terrorism in Pakistan. ${ }^{31}$ About the question of challenges or the grey areas left in NISP 2014 were addressed in NISP 2018-23, people were hopeful as newly elected prime minister Imran Khan, also assured that NACTA and NAP would continue its mandate to eradicate terrorism from Pakistan. Still a significant number of respondents did not have far idea about the road map laid down in NISP 201823. Lastly people were of the view that incidents of terrorism were decreased with the implementation of NISP but they also advocated this policy must be amended according to changing threat and peculiar conditions of Pakistan.

${ }^{29}$ Ayaz Khan, "Education Sector of Pakistan Next Victim of Terrorism." Pakistan Journal of International Affairs 2, no. 1 (2019)

${ }^{30}$ Moonis Ahmar, Can the PTI Eradicate Corruption? Daily Times, Lahore, 10 August 2018

${ }^{31}$ Anwar Iqbal, 'India mother of terrorism in South Asia,' Maleeha Lodhi tells UN' Daily Dawn, Islamabad, 24

September, 2017 


\section{Analysis of National Internal Security Policy 2014-18}

NISP 2014 was graded as a game changer for Pakistan in security domain because it was first ever policy of its kind and a distinct state's perspective on internal affairs. ${ }^{32}$ Major focus of this policy was on principles of mutual inclusiveness and integration of all national efforts. ${ }^{33}$ This document has comprehensive coverage of internal security issues and major internal threats are acknowledged by ministry level and clear guidelines are provided on the subject. Most impressive feature of this document is the inclusion of emerging facets of security and terrorism like economic terrorism, Countering Financing of Terrorism, development of data banks, human trafficking / smuggling, Intelligence Fusion Cells, Border Management System, countering violent extremism and madaris reforms etc. These were the issues which never addressed comprehensively in a single document by any government previously. There are 33 civil and paramilitary security agencies/forces operating in Pakistan having nearly comparable mandate like Police, Rangers, Frontier Constabulary (FC), Levis, Khasadars, Federal Investigation Agency (FIA), Central Investigation Agency (CIA), Counter Terrorism Department (CTD), Intelligence Beuru (IB), Inter-Services Intelligence (ISI), Military Intelligence (MI) etc. etc. NISP 2014 for the first time in the history of Pakistan provided a road map about the coordination mechanism of above mentioned agencies secondly the joint intelligence sharing was also introduced and documented for the first time.

\section{National Internal Security Policy 2018-23}

On 31 May 2018 government of Pakistan has announced national internal security policy (NISP) 2018-2023 which is a refined version of NISP 2014. It takes forward the previous policy 2014-18 by including the lessons learnt over the past four years. Impediments observed in previous policy are also incorporated with an exceptional degree of agreement by all the organs of the state. Consolidating the ability of the state to respond to security issues, challenging the ideological underpinnings of extremist narratives and addressing the dispossessions create a breeding ground for security challenges to emerge are focused in this document.

A refreshed security policy will provide the incoming government with a head start on the broad contours of domestic security policy while providing an opportunity to fine tune it according to its manifesto. ${ }^{34}$

Overall NISP 2018-23 is a polished document which has rectified the grey areas of previous policy of 2014. Implementation impediments of NISP 2014 definitely educated the policy makers to revamp their future security policy close to reality and as per the capacity of Pakistani LEAs. Roadmap of NISP 2018-23 is divided into total 120 interventions in which 51 are short term 44 are medium term and 82 are long term. These

\footnotetext{
${ }^{32}$ Muhammad Riaz Shad, and Sarfraz Ahmed. "Mainstreaming the Federally Administered Tribal Areas of Pakistan: Historical Dynamics, Prospective Advantages and Challenges." IPRI Journal 18, no. 2 (2018): 111136

${ }^{33}$ Stephen Tankel, “Confronting Pakistan's Support for Terrorism: Don't Designate, Calibrate.” The Washington Quarterly 39, no. 4 (2016): 165-179

${ }^{34}$ National Internal Security Policy 2018-2023, (Ministry of Interior, Government of Pakistan): 12
} 
120 interventions if carried out and undertaken as per plan may create positive effects on Pakistan's security. These interventions are described in following graphs with respect to time and nature of work:

\section{DISTRIBUTION OF PLANNED INTERVENTIONS IN NISP 2018-23 WITH TIMELINES ${ }^{35}$}

National Internal Security Policy of Pakistan is an aberration from the past trends of

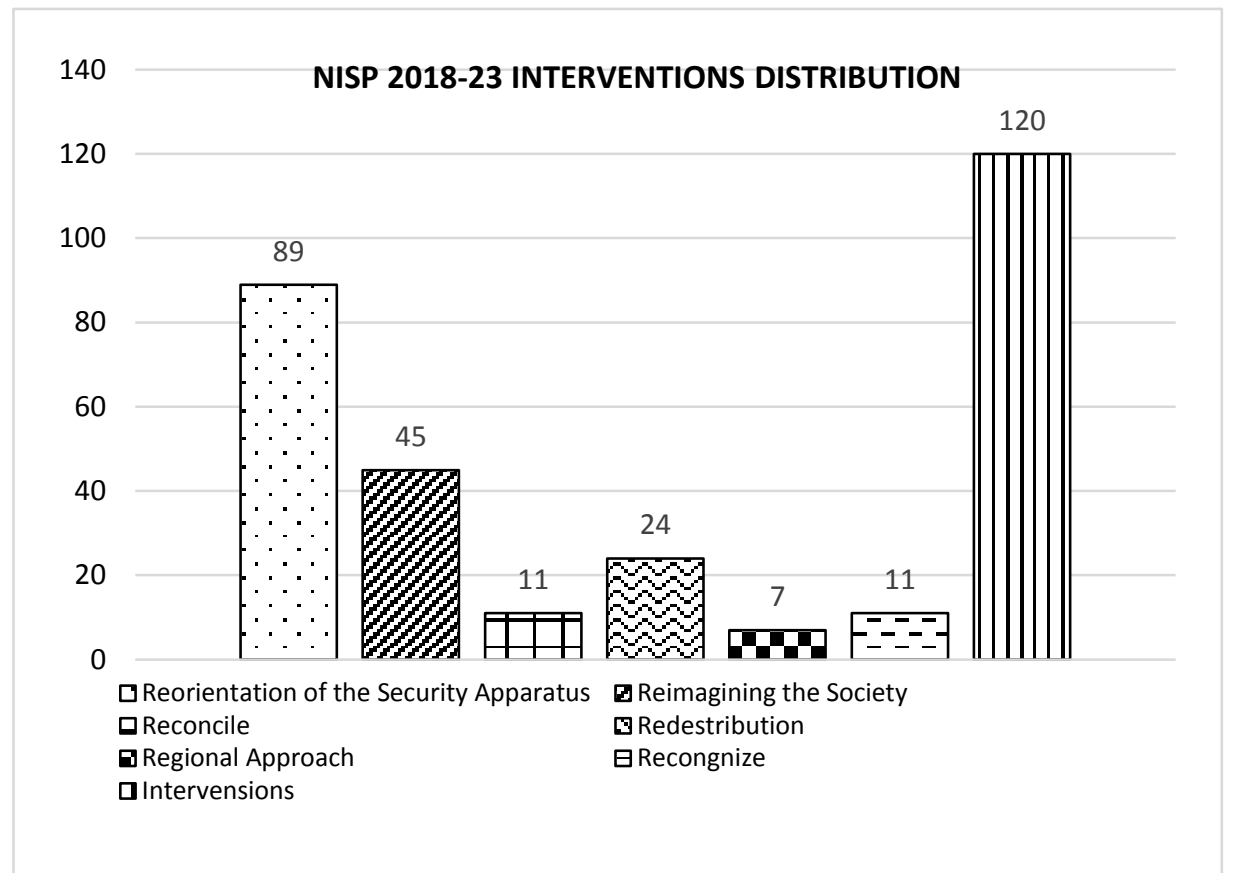

passing bills and legislations without assessing its applicability on ground. A holistic approach was at least adopted in NISP 2014 while NISP 2018 now encompasses a roadmap and an implementation strategy for Pakistan for the next one decade.

The first duty of a government is to maintain law and order, so that the life, property, and religious beliefs of its subjects are fully protected by the State ... if we want to make this great State of Pakistan happy and prosperous we should wholly and solely concentrate on the well-being of the people, and especially of the masses and the poor." Quaid-e-Azam Muhammad Ali Jinnah address to the Constituent Assembly of Pakistan (August 11, 1947) (36 $^{36}$

${ }^{35}$ Graphical representation of interventions and its timeline as planned in NISP 2018-23

36 Jawad Syed, "Pakistani Model of Diversity Management: Rediscovering Jinnah's Vision." International Journal of Sociology and Social Policy 28, no. 3/4 (2008): 100-113 


\section{Recommendations}

In todays developed world security has become a valuable commodity because security and economy are interlinked. Better security conditions are vital for sustaining all the

TIME-LINE OF PLANNED INTERVENTIONS FOR 2018-23

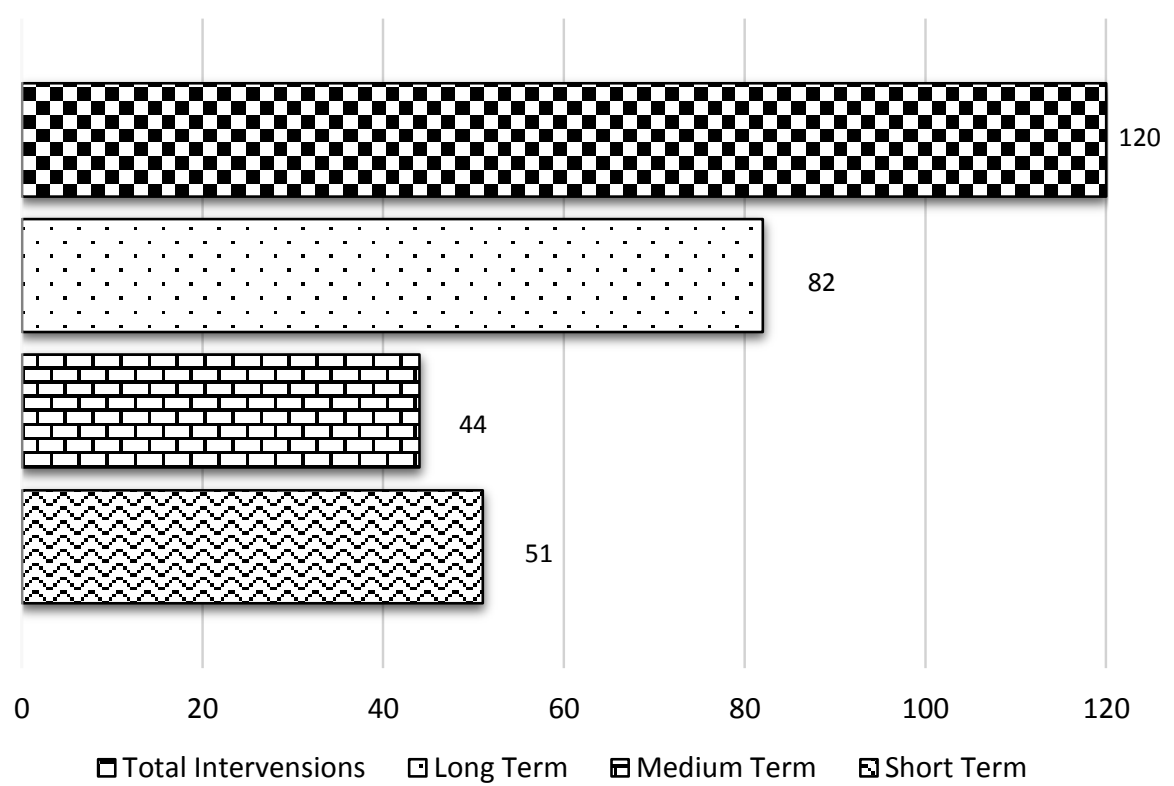

economic activities and same is true vice versa also. For Pakistan being a developing country an enabling and conducive environment is the need of the hour so that economic activities can take place throughout the country without any fear and resistance. In the past fifteen years all the security indicators of Pakistan drastically showed an alarming situation. In this back drop following are the few recommendations:

a) Pakistan has to revisit the lessons learnt in last fifteen years in the domain of security. ${ }^{37}$ No doubt it's a painful history but to avoid the recurrences of the same, NISP of Pakistan should be the vibrant and pragmatic document to issue clear, unambiguous and explicit guidelines against rapidly changing threat. Handling the security challenges of the $6^{\text {th }}$ most populous country of the world requires extensive planning and vision. Keeping in view today's formidable security and governance challenges, Pakistan cannot afford experiments in the domain of security policy making. There are living examples in the world where many nations have faced similar security challenges and successfully turned it into opportunities by better planning and consistency in policy implementation.

37 Abdul Basit, "Countering Violent Extremism: Evaluating Pakistan's Counter-Radicalization and Deradicalization Initiatives." IPRI Journal 15, no. 2 (2015): 44-68 
b) Pakistan security operators have to be cognizant of weakly governed spaces as it often becomes fertile breeding grounds for local, national and transnational terrorist groups. Alternative laws and justice systems rooted in tribal codes and customs must be replaced and checked. Uniform legal framework must be available for every part of the country.

c) Drivers of violence rooted in the social and political fabric of states must be identified and steps promised in NISP 2018 should address these issues.

d) Injustice, discrimination, corruption are the major causes of grievances at national level which are further exploited by terrorist and extremist groups. Mechanisms for transparency as promised by Prime Minister Imran Khan must be invoked in true letter and spirit. Weak institutional mechanisms for addressing corruption leads to defoliation of and rusting of all the institutes of the country and security institutions are no exception in this regard.

e) Fencing and biometric western border management can control the movement of terrorist sanctuaries across the border which was a serious threat to internal security.

f) Bleeding LOC between India and Pakistan have also contributed to the undermining of power potential of security agencies. Process of dialogue must be started between the two neighbors and efforts should be focused to create enabling environment for continuity of bilateral-talks.

g) During the course of the survey and interviews majority of the experienced officers had the view point that only coordination among various LAEs cannot serve the purpose instead amalgamation of different agencies into a singular force can solve the existing security issues. For example, if only single force with any name is responsible for security then it would be easy to implement a uniform training program for it. Unity of command would be it second benefit because under different commanders the focus on desired objectives usually get lost. It is recommended that all the existing LEAs under ministry of interior may be amalgamated into single security force with one uniform and standard training program. Under the continuation of same mindset, it is also suggested that single agency may also be developed for accountability, audit, monitoring and anti-corruption domains. Host of agencies like NAB, Anti-corruption, public audit committees and Mohtasib-e-Aala (Ombudsman) department etc may be placed under singular judicial command and single agency for anti-corruption and accountability be developed/created. Same issue now-a-days became a hot topic of national politics of Pakistan after the controversial presidential ordinance curtailing the NAB authorities. ${ }^{38}$ Military and government influence on these agencies are required to be curtailed for independent and efficient working, this can be achieved if these two major forces/agencies may directly be controlled by judiciary.

h) Poverty and low education are the contributing factors in political violence and extremism in Pakistan. ${ }^{39}$ Religious terrorism legalizes their idea of killings and violence as divinely sanctioned orders. Lack of transparency about national goals and the aligning of personal goals with the national goals in Pakistani youth for the reasons of corruption, political and leadership crisis have resulted in developing

${ }^{38}$ Amir Wasim, “Govt Rows Back on Move to Curb NAB Powers” Daily Dawn, 29.12.2019.

39 Zahid Shahab Ahmed, Farooq Yousaf, and Khan Zeb. "Socio-Economic and Political Determinants of Terrorism in Pakistan: University Students’ Perceptions.” International Studies 55, no. 2 (2018): 130-145. 
violent radical tendencies which have transpired in the form of unprecedented terrorism. Education budget must have to be given priority every year at the same time. Standard of public sector educational institutions should be improved and its modalities can be worked out to streamline this system and to avoid corruption. Literacy rate has direct bearing on the peace in the society.

i) The role of media is extremely crucial in todays globalized environment. ${ }^{40}$ It is most effective and efficient instrument also to curb social evils and terrorism / enhance morale of civil society. Media is also used as a tool of warfare. ${ }^{41}$ It also acts as watch-dog and a fourth pillar in a democratic system. In security domain media can negate false propaganda by anti-state elements and bring terrorists to justice. Handling of false news or fake news can be disastrous for society and its handling must be checked by PEMRA. Media must be given freedom but it should be conditional with national responsibility.

j) The trend in Pakistan is to abolish the previous government's good efforts and reinvent the step which causes hurdles in sustainability. Laws must be made at the institutional level to safeguard the continuity of development programs which often are disturbed with the change of governments. Governments should build on previous success irrespective of whose initiative was it for sustainability in governance and achievement of vision objectives. Newly elected Prime Minister of Pakistan has made announcement that NACTA will continue its mandate however it is needed that all the stake holders of the government and establishment strive for true implementation of NISP 2018-23. Government should encourage and organize international level Inter-faith dialogue on the lines of Paigam-e-Pakistan at regular intervals to improve the religious harmony and to negate sectarian killings in the region. ${ }^{42}$

k) Closer networking is needed between the subsystems of the criminal justice system. Practitioners should be trained in conflict resolution and management so that these techniques can be employed before resorting to force. There is a need to incorporate more changes in NISP-2014, including addressing the procedural and definitional issues. There should be safeguards to prevent terrorists from collecting funds and using infamous systems like hawala/hundi to move money from one place to another. This will help Pakistan to get out from FAFT grey list also. No new weapons licenses should be issued to such people and the licenses already issued should be cancelled. The government needs to regularize all commercial laws.

\section{Conclusion}

The security of Pakistan and its citizens is prime duty of the Government of Pakistan. NISP 2014-18 was a first serious step towards formulation of security doctrine of Pakistan. Respondents in the survey were particularly hopeful from the newly elected

40 John Baylis, The Globalization of World Politics: An Introduction to International Relations. (Oxford University Press, 2020).

${ }^{41}$ Sanda Svetoka, "Social Media as a Tool of Hybrid Warfare", (NATO Strategic Communications Centre of Excellence, 2016).

${ }^{42}$ Muhammad Ahmad Munir, "Paigham-e-Pakistan (The Message of Pakistan) II National Narrative Counter to Violence, Extremism, and Terrorism in an Islamic Perspective Translated by Muhammad Ahmad Munir." Islamic Studies 58, no. 1 (2019). 
government of Tehreek-e-Insaaf for eradication of corruption and rule of law in the country. Repeated operations by LAEs in last five years have improved the law and order situation around the country. Although the over ambition that was basically the byproduct of copying a doctrine from foreign sources has been exposed in these years, still some direction was assigned to Pakistani LAEs.

The range of hard and soft security measures that the government adopted over the past five years needs further improvement. National Internal Security Policy (NISP) 2014 has refined much in its 2018 version and the lessons learnt during these five years are largely evident in this recent document but on the practical grounds still over complacency is observed at various tiers of security. Ongoing kinetic operations Raddul Fasaad requires constant monitoring and resolve because track record of terrorism in Pakistan shows that it shrinks from areas and cities to slums and sleeping cells and again reemerges from anywhere with more magnitude and intensity. Suicidal attacks during general elections 2018 and increased violence and crime rate in Karachi and other cities are case in point. This ensures that the internal security situation is continuously evolving and new challenges are emerging each day.

In order to consolidate the efforts and sacrifices of Pakistani security men and officers over the past years and to address the emerging challenges, the government in consultation with all major stakeholders has to devise a comprehensive implementation framework for dealing with the multi-faceted threat of violent extremism and terrorism along with other security challenges. Promotion of inclusive and sustainable development and re-imagining and strengthening of the state-citizen relationship should be the security approach as it is promised in NISP 2018-23.

Values like rule of law, inclusive growth and respect for diversity for achieving sustainable peace and security are required to be marketed more aggressively. Tolerant teachings of Islam to foster a counter-narrative against extremism and terrorism are need of the hour to be disseminated at all levels of the country. Pakistan is a country of resilient people and its history shows that its people have always rejected the forces of extremism and terrorism. National resolve must be triggered for peaceful Pakistan.

\section{Bibliography}

Ahmar, Moonis. The Challenges of the Conflict Resolution and Security in 21st Century: Problems and Prospects. (Karachi: Dept. of International Relations, University of Karachi, 2001).

Ahmed, Zahid Shahab, Farooq Yousaf, and Khan Zeb. "Socio-economic and political determinants of terrorism in Pakistan: University students' perceptions." International Studies 55, no. 2 (2018).

Ahmed, Rana Nabeel, and Kahlil Ahmad. "Impact of Population on Economic Growth: A Case Study of Pakistan." Bulletin of Business and Economics (BBE) 5, no. 3 (2016). 
Ali, Abdullah Yusuf. "The Holy Quran (Koran)." Madinah: King Fahd Printing Complex (1987).

Apergis, Nicholas, and Marina-Selini Katsaiti. "Poverty and the resource curse: Evidence from a global panel of countries." Research in Economics 72, no. 2, 2018.

Azam, Maryam. "Genesis and Dimensions of Religious Militancy: Implications on the Internal Security of Pakistan (2001-2015)." PhD diss., University of the Punjab, Lahore, 2019.

Adamson 1, Fiona B. “Globalisation, transnational political mobilisation, and networks of violence." Cambridge Review of International Affairs 18, no. 1 (2005).

Ball, Stephen J. "Markets, equity and values in education." Affirming the comprehensive ideal, 1997.

Bandura, Albert, and Richard H. Walters. Social learning theory. Vol. 1. Englewood Cliffs, NJ: Prentice-hall, 1977.

Baylis, John. The globalization of world politics: An introduction to international relations. Oxford University Press, 2020.

Basit, Abdul. "Countering violent extremism: evaluating Pakistan's counter-radicalization and de-radicalization initiatives.” IPRI Journal 15, no. 2 (2015).

Butt, Usama. Pakistan's Quagmire Security, Strategy, and the Future of the Islamicnuclear Nation. New York: Continuum, 2010.

Buhari-Gulmez, Didem. "Crisis" and Crimean Tatars: Discourses of Self-determination in flux." In Crisis and Change in Post-Cold War Global Politics, pp. 203-224. Palgrave Macmillan, Cham, 2018.

Cavelty, Myriam. The Routledge Handbook of Security Studies. Milton Park, Abingdon, Oxon: Routledge, 2010.

Chayes, Sarah. Thieves of State: Why Corruption Threatens Global Security, Washington DC Norton, 2015.

Enders, Walter, and Todd Sandler. The political economy of terrorism. Cambridge University Press, 2011.

Elahi, Urwa, and Umbreen Javaid. "Operation Zarb e Azb: A Decisive Strike." Pakistan Vision 20, no. 2 (2019).

Federico, Christopher M., and Ariel Malka. "The contingent, contextual nature of the relationship between needs for security and certainty and political preferences: Evidence and implications." Political Psychology 39, 2018.

Felson, Marcus. "Linking criminal choices, routine activities, informal control, and criminal outcomes.” In The reasoning criminal, pp. 119-128. Routledge, 2017.

Frosh, Stephen. Identity crisis: Modernity, psychoanalysis and the self. Macmillan International Higher Education, 1991. 
Fox, Jonathan. An introduction to religion and politics: Theory and Practice. Routledge, 2018.

Gurr, Ted Robert. Why Men Rebel. (Routledge, 2015).

Hameed, Abdul, and Shahid Karim. "Multidimensional Poverty Mapping for Rural Pakistan." In This paper has been presented at 1st International Conference on Business, Economics, \& Education Management-ICBEM (Sukkur: Institute of Business Administration 2016).

Haas, M. de. "Security Policy and Developments in Central Asia: Security Documents Compared with Security Challenges." The Journal Of Slavic Military Studies 29 (2016).

Hudson, Rex A. Who Becomes a Terrorist and Why? The Psychology and Sociology of Terrorism. Skyhorse Publishing Inc., 2018.

Lieven, Anatol. Pakistan: A Hard Country. (London: Allen Lane, Penguin, 2012).

Johnson, Robert. "Hybrid War and its Countermeasures: A Critique of the Literature." Small Wars \& Insurgencies 29, no. 1 (2018).

Khattak, Masood Ur Rehman, and Mansoor Akbar Kundi. "Conventional Asymmetries between India and Pakistan: A threat to the Deterrence Stability of South Asia." Journal of Political Studies 26, no. 1 (2019).

Lodhi, Maleeha. Pakistan: Beyond the "Crisis State" (NY: Columbia University Press, 2011).

Markey, Daniel Seth. No Exit from Pakistan: America's Tortured Relationship with Islamabad, (NY: Cambridge University Press, 2013).

McAdam, Doug. Political Process and the Development of Black Insurgency, 1930-1970. (University of Chicago Press, 2010).

Munir, Muhammad Ahmad. "Paigham-e-Pakistan (The Message of Pakistan) II National Narrative Counter to Violence, Extremism, and Terrorism in an Islamic Perspective Translated by Muhammad Ahmad Munir." Islamic Studies 58, no. 1 (2019). National Counter Terrorism Authority (NACTA), official web page, sub link: about us, Strengthening of NACTA, 2018, Government of Pakistan, website: http://www.nacta.gov.pk.

Mufti, Khalid A., Ali Ahsan Mufti, and Michaeline Bresnahan. "The Army Public School Massacre in Peshawar, Pakistan." In an International Perspective on Disasters and Children's Mental Health, pp. 63-71. Springer, Cham, 2019

Pfundmair, Michaela. "Ostracism Promotes A Terroristic Mindset." Behavioral Sciences of Terrorism and Political Aggression, 2018.

Orakzai, Saira Bano. "Pakistan's Approach to Countering Violent Extremism (CVE): Reframing the Policy Framework for Peace-building and Development Strategies." Studies in Conflict \& Terrorism, 2018 
Ross, Jeffrey Ian. "A Model of the Psychological Causes of Oppositional Political Terrorism." Peace and Conflict 2, no. 2 (1996)

Sandler, Todd, John T. Tschirhart, and Jon Cauley. "A Theoretical Analysis of Transnational Terrorism.” American Political Science Review 77, no.1 (1983)

Saleem, Hummera, and Muhammad Bilal Khan. "Multidimensional Poverty in Pakistan: A Policy Perspective." In Proceedings of the 4th International Conference on Poverty and Sustainable Development, vol. 4, (2017)

Schumpe, Birga M., Jocelyn J. Bélanger, Manuel Moyano, and Claudia F. Nisa. "The Role of Sensation Seeking in Political Violence: An Extension of the Significance Quest Theory." Journal of Personality and Social Psychology, (2018).

Sukarieh, Mayssoun, and Stuart Tannock. "The Global Securitisation of Youth." Third World Quarterly 39, no. 5, 2018.

Stankov, Lazar, Gerard Saucier, and Goran Knežević. "Militant Extremist Mind-set: Proviolence, Vile World, and Divine Power.” Psychological Assessment 22, no. 1, 2010.

Sandler, Todd, John T. Tschirhart, and Jon Cauley. "A Theoretical Analysis of Transnational Terrorism” American Political Science Review 77, no. 1 (1983).

Singh, Bawa. "Peace-making in Afghanistan: Heart of Asia is in Question." FOCUS 1, no. 28 (2017).

Syed, Jawad. "Pakistani Model of Diversity Management: Rediscovering Jinnah's vision." International Journal of Sociology and Social Policy 28, no. 3/4 (2008).

Tankel, Stephen. “Confronting Pakistan's Support for Terrorism: Don't Designate, Calibrate." The Washington Quarterly 39, no. 4 (2016): 165-179.

Stankov, Lazar, Goran Knežević, Gerard Saucier, Borislav Radović, and Biljana Milovanović. "Militant Extremist Mindset and the Assessment of Radicalization in the General Population" Journal of Individual Differences (2018).

Wither, James K. "Making Sense of Hybrid Warfare." Connections (18121098) 15, no. 2 (2016).

Victoroff, Jeff. "The Mind of the Terrorist: A Review and Critique of Psychological Approaches." Journal of Conflict resolution 49, no. 1 (2005). 